Article

\title{
Becoming and Being Irish-Pākehā: Crafting a Narrative of Belonging That Inspirits Indigenous-Settler Relationships
}

\section{Frances Hancock (D)}

School of Māori and Indigenous Education, Faculty of Education and Social Work, University of Auckland, Auckland 1010, New Zealand; f.hancock@auckland.ac.nz

Received: 27 September 2020; Accepted: 18 November 2020; Published: 24 November 2020

\begin{abstract}
Irish-Pākehā (a European New Zealander of Irish descent) is a settler identity that embodies ancestral relations with forebears and homelands as well as a relationship with Māori, the Indigenous Peoples of Aotearoa-New Zealand. Being of Irish descent carries multiple meanings that can nourish a sense of identity, a sense of belonging, and significant relationships. How have my Irish ancestral relations and places of belonging cultivated in me those relational qualities and ethical-political commitments that inspirit the Indigenous-settler engagements that are part of my personal and professional life? Here I explore the complexities of becoming and being Irish-Pākehā in response to that question. Travelling across generations and two countries, I utilise a series of guiding questions to help construct an Irish-Pākehā diasporic identity through a narrative of belonging. Following Nash, I explore geographies of relatedness, doing kinship, and the effects of identity-making through kinship as a way to understand who I am/am becoming and why being Irish-Pākehā matters in my work with Indigenous Māori.
\end{abstract}

Keywords: Irish-Pākehā identity; diasporic identities; ancestral relations; ethical-political commitments; narratives of belonging; narrative inquiry; Indigenous-settler relations; Māori-Pākehā relations; decolonising educational research

\section{Two Places of Belonging}

My great-grandmother Catherine was one of five sisters who joined the Irish diaspora. She landed in Aotearoa-New Zealand in 1884, where she lived in a small town among other Irish settlers. Notwithstanding the oppressive history of colonisation in Ireland, her voyage across the world conspired with the British imperialist project and she became a settler. The expansion of British imperialism to Aotearoa-New Zealand introduced colonial structures, systems, laws, processes, and practices that systematically and systemically contrived to dislocate and dispossess Māori (the Indigenous Peoples of Aotearoa) from/of their lands and other taonga (ancestral treasures). It sought to usurp Māori sovereignty and political status, undermining their human rights to maintain their ways of living and determine their futures. ${ }^{1}$

As part of the great incoming tide of settlers, my great grandmother, my grandmother, my mother, and I became beneficiaries of British imperialism. Our family inhabited a society governed by European values and systems that served the interests of our people, but marginalized, ignored, and sought to erase Indigenous Māori ways of being, thinking, and doing. Despite some incremental change in Aotearoa-New Zealand over my lifetime (nearly 60 years), Māori remain significantly disadvantaged across a suite of wellbeing measures;

1 See Mason Durie (1998) for mechanisms employed by the colonial government to usurp Māori sovereignty and political status as well as enable the dislocation from and dispossession of their lands and other resources. 
daily they are exposed to a raft of inequities and various forms of covert/overt racism, and are routinely deprived of opportunities (including to be seen and heard in certain arenas) that I take for granted. ${ }^{2}$ I have dedicated my life to responding to this ongoing deadly injustice and find strength to continue in my ancestral relations, in places where I experience senses of belonging and, especially, in my rich relationships with Māori.

Every generation since my great grandmother's arrival in Aotearoa, the New Zealanders (as my Irish cousins call us) have returned to Ireland, and the Irish (as we call them) have come this way. The feelings of belonging to one another and our relationships to these two places remain intimate to this day. Not everyone in 'the family', on either side of the great oceans that separate us, feels the way I do about those relationships. But this feeling I have for my maternal ancestors and my place of origin has profoundly shaped who I am, including my orientation to the Indigenous Peoples of Aotearoa and their struggles for justice.

To be a Pākehā (a New Zealander of European descent) $)^{3}$ is to be in relation to Māori, to grapple with the complex histories of a small island nation and to be shaped by this whenua (land). When I introduce myself to Māori, I say: 'I belong to two places_Ireland and Aotearoa.' Ireland is my ancestral home, where I am a citizen, where my ancestors are buried and my cousins live. Aotearoa is my place of birth, where I reside and will be laid to rest. Knowing to whom and where I belong supports me every day to engage with Māori, for whom whakapapa (origins/ancestral relations/genealogical descent lines) and türangawaewae (a place to stand) mean so much.

I open with an extract from my evolving 'narrative of belonging' ${ }^{4}$ to signal the identity-making work at the heart of this paper. In the discussion below, I explore and respond to some of the complexities of knowing myself as a third generation Irish-Pākehā settler of Aotearoa-New Zealand with deep connections to Ireland, my ancestral place of origin. As a writer and community consultant, I have worked alongside Māori, the Indigenous Peoples of Aotearoa, in various capacities for more than three decades. Since 2015, I have contributed to the nationally recognised Indigenous-led, community-supported political action campaign Save Our Unique Landscape (SOUL), also known as \#ProtectIhumātao, near where I live in Auckland (Hancock et al., forthcoming; Malva 2018). This campaign aims to stop a transnational corporation from building houses on culturally significant whenua (land) at Ihumātao, which was unjustly confiscated from Māori in 1863 by the colonial government (McCreanor et al. 2018). Constantly I confront this question: How do I engage productively with Māori in the work we are doing together? If being Irish-Pākehā matters, how do my ancestral relations cultivate relational qualities and ethical-political ${ }^{5}$ commitments in me that encourage and guide my Indigenous-settler engagements in the present?

We Pākehā are constantly challenged to locate ourselves when working with Māori. 'Ko wai au?' (who am I?) and 'Nō hea au?' (where am I from?) are questions we must be able to answer when seeking to engage in productive, ongoing cross-cultural relationships. Irish-Pākehā educator Ted Glynn (2013) observes that when considering collaborative research or a shared enterprise, Māori are interested in the significant places and kinship networks that define people. Tertiary students in education, social work, and sociology (disciplines with which my own work in academia intersects) are often required to write essays exploring aspects of their own ethnic identities. This can be a confronting task for Pākehā students who, as members of a numerically dominant and socially privileged group, are unused to seeing themselves as belonging to a distinctive cultural and ethnic group (Liu 2005). How do I/we, as settlers, come to know and name ourselves in the context of our genealogies, relationships to place/s

2 See A. Mikaere (2011) for a discussion on racism and other strategies that support inequities and undermine Māori wellbeing in contemporary society.

3 In this paper, I use common Māori language words. Te reo Māori (the Māori language) is an official/national language of Aotearoa-New Zealand. It remains endangered, like many other Indigenous languages, but is undergoing revitalisation.

4 This paper is part of a broader project focussed on Māori-Pākehā/Indigenous-settler relations (Hancock 2018). I include three narrative extracts drawn from that broader project (pp. 5-10), which I reworked and further developed here. Eventually I intend to weave these and other narratives into a memoir. Elsewhere (Hancock, forthcoming), I reflect on my ongoing engagement with a group of Indigenous and non-Indigenous peoples in Maine and New Brunswick in North America through a relationship building initiative, The Gatherings, that took place over some years in the 1980s and 1990s, and more recently became a 13-year book project.

5 I hyphenate ethical-political because I consider the ethical and the political inextricably interwoven (see Hancock 2018, p. 4). 
and to Māori presence, difference, and political status? What method and guiding questions can assist us to craft a narrative of belonging? Here, I outline an approach that helped me to begin constructing such a narrative, with a mainly settler readership in mind.

I begin by exploring meanings of the generic terms Indigenous and settler and Māori and Pākehā. I then discuss notions of ancestral relations, place, and belonging as they relate to Irish diasporic identities (Nash 2005, 2008, 2017; Lipman and Nash 2019), highlighting three key ideas-geographies of relatedness, doing kinship, and the effects of identity-making through kinship. Here, I use these ideas to focus my narrative and analytical work. To emphasise the importance of stories as a resource to think with, I situate my narrative of belonging and its identity-making effects within the terrain of narrative inquiry, but it is also a form of decolonising educational research. ${ }^{6}$ I include a series of guiding questions to support meaningful storytelling when crafting a narrative of belonging. As an example of this method put into practice, I present further excerpts from my own evolving narrative of belonging. I conclude with musings, necessarily in-the-making, on what it means to become and be Irish-Pākehā. I reflect on the affinities and ambivalences in such identity practices in the context of Aotearoa-New Zealand and how these and other elements continue to inspirit my experience of and openness to Indigenous-settler relations.

\section{Indigenous and Settler Identities}

The terms Indigenous and settler evoke a range of meanings. Such labels are problematic-troubling, contradictory, contested, and oppositional—because they camouflage or deny particular identities and histories (Hancock 2018). Yet, they can also work productively to mobilise a sense of solidarity. Linda Tuhiwai Smith (2012) argues that the term Indigenous not only groups together diverse Indigenous peoples who endured unique experiences of imperialism, but also-positively—highlights the global significance of the experiences, interests, concerns, and struggles of Indigenous peoples, drawing attention to their right to self-determination and an international network of belonging. The incommensurable differences of Indigenous peoples and settlers are not easily categorised; "we are always on the move, always in a state of flux, always different to each other no matter what" (McAllan 2013, p. 4).

In Aotearoa-New Zealand, the identity markers Māori and Pākehā sit within the broader Indigenous-settler framework, and are also variously understood and contested. The adjective 'Māori' means 'ordinary'. It became normalised as a term to distinguish the local Indigenous peoples from white settlers (Pākehā): "Each term forced the other into being" (Jones and Jenkins 2008a, p. 473). The term Māori thus draws attention to a colonial relationship between Māori and Pākehā but, as with Indigenous peoples elsewhere, Māori already had their own identities (Smith 2012). Early settlers used the newly coined noun 'Māori' to collectivise a tribally based society. This noun/name is now commonly used by Māori to refer to their collective interests. The term is also now understood by many as an ethnic group or cultural identity (Royal 2012). Any discussion of Irish-Pākehā identity necessarily implicates and must attend to settler colonial relations with Māori.

Likewise, the term Pākehā is contested. As a "taonga, a gift, from Māori", this term offers possibilities for relationship and is a critical reminder that "there is nowhere else in the world that one can be Pākehā" (Mikaere 2011, p. 2011; Bell and McGuire 2019). For some, it evokes an emerging, mixed, white, and haunted identity (Fitzpatrick 2018). Others focus on shared cultural values and behaviours derived from being part of the dominant group of European New Zealanders (Fleras and Spoonley 1999). While the term Pākehā could represent "a developing and distinct culture, and the identity that goes with that", many still reject it, and its adoption as an identity label remains provisional (Bell and McGuire 2019; Matthewman and Hoey 2007). Discrepancies in its use thirty years ago are still apparent today:

6 I use the terms "narrative" and "story" interchangeably. 
"'Pākehā' is widely used within Aotearoa New Zealand as a category to name the dominant group. However, that group does not have the sense of self-conscious cohesion and solidarity that typically marks an ethnic community. In other words, New Zealanders tend to use 'Pākehā' objectively rather than subjectively". (Pearson 1989 cited in Bell 2006, p. 264)

Historian Michael King (1999) provocatively suggested that Pākehā are "another kind of indigenous New Zealander" (p. 239), a "second indigenous New Zealand culture" (p. 40, italics in the original). He argued that Pākehā became indigenous when their sense of identity and commitment became grounded in New Zealand rather than their country of origin. For that reason and their own historical, geographical, and spiritual relationships to the land of Aotearoa (in his case, developed over generations), Pākehā should be accorded the same status as Māori. I and other scholars reject his arguments. Matthewman and Hoey (2007) suggest that a settler/Pākehā desire for indigeneity relies on selective memories, forgetting their own history and masking privilege. "Living in the present" allows Pākehā to remain "innocent of past transgressions", as if we Pākehā have no history, but "of course, what is forgotten and why are of crucial importance," (p. 5). Matthewman and Hoey argue that Pākehā mimicry "arises because of difference, and it seeks to erase that difference through arguments for (moral) equivalence" (p. 4). King (1999) proposal of Pākehā indigeneity (a term he uses interchangeably with "white native") denies or conveniently forgets that colonial strategies (Native land legislation and language policies, for example) privileged settler interests at the expense of Māori Indigeneity, engineering but ultimately failing to achieve cultural genocide (Bidois 2013; Durie 1998; Hancock 2018; Mikaere 2011; Smith 2012).

However it is understood, the term Pākehā speaks of and to Aotearoa. ${ }^{7}$ Describing Pākehā as "a relational identity", Jones (2020) observes that "to be Pākehā, to fully inhabit that identity, is to be permanently oriented to Māori, as well as to know about our historical entanglements ... [it is] to be peculiarly located here, with Māori" (p. 190). Wevers (2006) proposes that Pākehā adopt the complex yet flexible positioning of "a diasporic identity" which accepts the relationship that founded the country and "describes why we [Pākehā] choose to be here [or are here], the grounds on which we are here and what we should do about it" (p. 8). Here, I recognise that the term Pākehā symbolises a relationship to Aotearoa and its Indigenous peoples, as well as calling attention to "a brutal colonial past" that forced new, unjust, unequal power relations (Mikaere 2011, p. 9). European New Zealanders with Irish descent may be considered one of many diasporic identities represented by this term, but we also embody our own cultural and historical differences.

Some scholars have explored what an Irish-Pākehā identity means. A second generation Pākehā of Irish descent, Ted Glynn (2013) emphasises ancestral relationships and stories attached to particular places and landscapes. When tracing his own Irish ancestry in Ireland, he encountered a sense of deep loss from severing a relationship to place when escaping colonial rule. He questioned if he had ever understood the fatal loss of land, language, and culture that Māori suffered through colonisation and land wars, and their concomitant effects. Formative journeys to Ireland shaped his identity and experiences both as a person and as an educational researcher. Collaborations with Māori led him to deeply value the importance of appreciating the experiences and world view of Māori on their terms.

Celine Kearney is the granddaughter of three Irish-born grandparents. Her narrative inquiry research (Kearney 2016; Kearney and Andrew 2019) with 25 people of a Celtic/Gaelic background living in New Zealand illustrates a dynamic, relational, and multifaceted identity that she calls 'Southern or South Pacific Celts'. Her study illuminates the relationship between geographical and internal landscapes. One participant discussed what he perceived as his Irish-born father's struggle to land in Aotearoa-New Zealand and talk from this new place: "I finally understood my father was actually talking from his native landscape, not the New Zealand landscape" (Kearney and Andrew 2019, p. 353). He also spoke of places in Ireland that reminded him of where he lives in Aotearoa-New

7 See also Steve Matthewman (2017) for a comprehensive sociological account of Pākehā identity and privilege. 
Zealand. Kearney's participants valued the Irish language as an expression of culture, but felt ambivalence living in a country with few Irish speakers. Participants also perceived parallels between Irish and Māori histories of colonisation, rituals, oral and tribal societies, and relational ways of being (Kearney 2016). However, a number observed that while colonisation was imposed on both countries, that did not necessarily encourage relationships between Irish settlers and Māori; and Irish settlers became beneficiaries of, and some soldiers for, British imperialism. One participant, who spent decades educating Pākehā about New Zealand's colonial history, observed that if Pākehā knew their story and why their people left Ireland, they might become allies of Māori (Kearney 2016; Consedine and Consedine 2012). The importance of remembering history, of knowing your own story and of learning from ancestral relations and significant others, especially Māori, as a critical form of knowledge underpins my narrative, decolonising work in this paper.

\section{Ancestral Relations and Irish Diasporic Identities}

Irish feminist cultural geographer Catherine Nash has written extensively on changing notions of Irishness, Irish identity, and the significance of ancestral relations, place, memory, and belonging for ethnic, national, and diasporic identities. Her invigorating research arises from her own explorations (personal and academic) of "who belongs in a place and on what basis, ... and to whom places belong, both imaginatively and within the formal politics of statehood and citizenship" (Nash 2008, p. ix). She argues that exploring ancestry, origins, place, and identity exposes complex geographies and relational entanglements that implicate a broader politics of belonging and defy simplistic renderings or fixed categories. Such explorations, and their intersections, are often "deeply personal", "intimate", "entangled", "never-ending", and "never-straightforward" (p. x). They are also "deeply political" and "potent" (p. 6). Her observations resonate with my experience of intergenerational relationships to an origin place and a birthplace, as well as my sustained engagements with Māori over decades, all of which challenge my sense of identity and belonging. Three key ideas from Nash, inextricably linked but distinguished here, helped me to navigate these challenges when thinking about and crafting my narrative of belonging.

The first idea focuses on relatedness. Traversing an aspect of what Nash calls 'geographies of relatedness' my research seeks to attend to the specificity and constitutive power of both genealogical narratives and place- "the original homeland and the homes made through migration" (Nash 2008, p. 267). Nash argues that explorations of genealogical narratives and places of belonging can enable people to make and remake relations, as well as providing the basis for a cultural and political identity. An Irish diasporic identity, she observes, challenges the idea that "being born and bred" in Ireland is essential for a sense of belonging to ancestors/place of origin (Nash 2008). She also observes that settlers may respond to the challenges of Indigenous rights by pursuing a sense of indigeneity. They may search for a place of origin- "a place of domicile and descent" - where they are "ancestrally at home", where they, too, have "an ancient presence" (Nash 2008, p. 266). My research is not motivated by a quest for indigeneity. Rather, in my case, the concept of relatedness supports an array of meaningful affiliations, including multiple homes, deeply felt associations, and different places of belonging.

The second idea is that genealogy sits within a broader project of doing kinship. As "a practice of making relations", doing kinship recognises and encompasses relationships with significant others who do not share genealogical connections (Nash 2017, p. 5). Making "blood a fundamental but flexible criterion for relatedness" (Nash 2005, p. 452) means that "kinship is given and made" — within and outside families in ways that nourish "relational selves" and identities (Lipman and Nash 2019, p. 276). Doing kinship involves a process of selecting significant relationships (with ancestral, birth, or other favoured places, family lines, and relationships outside the family) and steering away from others for various reasons (familial, emotional, spiritual, political, financial, or convenience). It creates imaginative and embodied possibilities for relatedness based on "shared goals, senses of interdependence and the negotiation of difference" (Nash 2008, p. 268). Nash's expansive notion of doing kinship within and outside blood ties is an important concept for my research because it allows for a range of significant 
relationships (including, and especially in my case, with Indigenous Māori) to inform my narrative of belonging.

The third idea concerns the effects of identity-making through kinship. Nash (2008) explains that people may experience "familiarity" and "affinity" when visiting their ancestral homeland and tracing ancestors, or wrestle with a sense of "antipathy" and "ambivalence", especially when encountering complex histories and negotiating differences (p. 270). Pākehā of Irish descent may uncover ancestors who experienced the full force of colonial oppression, while other forebears who emigrated to Aotearoa-New Zealand became settlers participating in and benefiting from colonisation, with Māori enduring devastating, ongoing impacts. Disrupting attachments to personal, collective, and national identities (that are connected to cultural/physical geographies and tie shared descent to a homeland) creates possibilities for new bonds. These bonds can deepen relationships to or illuminate differences within broader collective or national identities. Nash's observation that negotiating complex histories and differences can mobilise political commitments resonates with my own experiences as an Irish-Pākehā who has forged alliances with Māori.

\section{A Method for Crafting a Narrative of Belonging}

Doing kinship is imaginative, social, and narrative work as well as, here, a form of decolonising educational research. As a narrative enterprise, it interweaves the personal and social, the past, present, and future, and place, space, and environment (Clandinin and Connelly 2000, p. 50). Decolonising educational research requires ethical-political consideration of critical histories, relational ways of knowing, who can know, on what basis, as well as being answerable to particular Indigenous peoples in a particular place and a community of critical scholars (Patel 2016; Smith 2012). Inevitably, doing kinship challenges people/scholars to fill in knowledge gaps, explore a range of relationships (with places and peoples), confront or ignore colonial histories, and craft stories (orally or in writing) that they (their families and others) can think with, and use to explain 'who I am', 'where I am from' and 'what that means'. For this reason, kinship work not only requires determination and effort (Nash 2008, p. 270), but also accepts that the lives and identities being crafted remain a work in progress (Clandinin and Connelly 2000, p. 166).

Taking up a methodological challenge to think with stories (Frank 2004, 2010; Archibald 2008; Archibald et al. 2019), here I weave narrative inquiry with a decolonising educational approach. ${ }^{8}$ In this methodological terrain, stories lived and told become a means of understanding how individuals, groups, communities, and nations think, feel, act, know, as well as interpret and express meaning (Bruner 1986; Clandinin and Connelly 2000). Certain stories do ethical, moral, and political work-they teach, they challenge, they question or encourage commitments, they call people to action, and so on (Frank 2004, 2010). Such stories have a capacity to re-present who people are and who they are becoming (Mattingly 2010). As 'counterstories', they summon respect for the ethical-political commitments they express and seek to resist and repair oppressive identities (Nelson 2001). Indigenous scholars highlight that stories/storytelling enable individuals and groups to perform their relations, identities, knowledge, and aspirations in diverse contexts for various purposes (Bishop 1996). Such decolonising 'storywork' embodies and implicates histories of and relationships to people/s—past, present, and future-and to place/s (Archibald 2008; Archibald et al. 2019). My research approach here seeks to constitute, critically understand, and make meaning of ancestry, origins, place, and belonging, as narratives, as knowledge, and as a genealogical and cultural practice (Nash 2008).

In crafting a narrative of belonging, I employed the three interrelated ideas from Nash outlined in the previous section as a narrative focus and analytical lens. I selected and critically engaged with

8 I did a narrative inquiry apprenticeship over many years with David Epston (Hancock and Epston 2008), who with Michael White co-founded the field of Narrative Therapy, so I think of my methodological interests in terms of narrative inquiry and decolonising approaches (see Hancock 2018, 2019). My approach may also be considered autoethnographic or memoir, and I welcome those interpretations. 
particular transformative relationships to places of belonging, significant ancestors and their living offspring (mainly women), and Indigenous peoples. Growing up, I was significantly influenced by the presence of my mother and stories of our maternal ancestors-both cultivated a powerfully gendered view of reality. Here I seek to make and remake relationships that have something to teach me and possibly others about what it means to become and be Irish-Pākehā.

Reimagining these relationships as stories to think with, I explored two storylines, each informing the other. The first focused on my evolving sense of being Irish: My place of ancestral origin and relationships with significant ancestors and cousins. The second focused on my sense of becoming Pākehā: My place of birth, where I live, and my relationships with Māori. My purpose was to reflect on "what it means to situate oneself historically and geographically through genealogy" and how such meaning-making can be mobilised politically (Nash 2008, p. 271). As a way to begin crafting a narrative of belonging, I considered questions:

On relatedness: Where do I feel a strong sense of belonging to an ancestral place and who or what connects me there? What stories can I tell that express how my ancestral place of origin and/or birthplace has challenged or nourished my sense of belonging to place? Thinking about living in Aotearoa and becoming and being [Irish] Pākehā, how do I see myself in relation to Māori and positioned politically in society?

On kinship: To whom do I belong and draw strength from? What stories can I tell stories of particular ancestors, living family members, or significant others who have been significant in shaping my identity and commitments, and how? Looking back on my life, what significant relationships, events, or encounters drew my attention to the presence and interests of Māori? How did those engagements shape or challenge my evolving sense of identity as an [Irish] Pākehā? Alternatively, how might I explain their absence?

On effects of identity-making through kinship: What stories of significant ancestors or others can I tell that illuminate qualities and commitments I cherish, and why? How do I/can I mobilise these qualities and commitments in my work for justice, now and in the future? Thinking about complex histories and differences, what affinities and ambivalences have I experienced as an [Irish] Pākehā? What do they/might they make possible in my relationships with Māori now and in the future?

I allowed this series of questions to act as a guide rather than as a prescription, working on my imagination and heart. When I began to write, I recalled lived experiences and stories that expanded my understandings of kinship and two distinct places of belonging in ways that source and resource my evolving ethical-political commitments in the present. I wanted to craft 'a good story' that would encourage readers to join me in doing kinship and narrative work. A characteristic of "a good story is its openness-the way you or I or anyone reading it can take it in, and use it for ourselves" (Coles 1989, p. 47).

To help me respond to the guiding questions presented above and to produce the narrative of belonging that follows, I drew on a variety of archival sources. Details of family history came from research in the national archives of Ireland and New Zealand that uncovered birth, death, and marriage records/certificates as well as shipping/assisted passage records. Conversations with family members in both places generated the family stories featured here. Irish cousins gave me copies of family letters written decades ago, showed me other artefacts, took me to significant places in Ireland, and gave me family photographs. I also gleaned information from a family tree created by our New Zealand family historian. New Zealand and Irish kin read and discussed the stories below, which supported a shared sense of understanding and ensured accuracy. I engaged with my Māori colleague Pania Newton over the inclusion of stories drawn from our current political work at Ihumātao; we are currently doing other co-authored work focussed on Māori-Pākehā relations and our experiences of working closely together. While our stories interweave here, in choosing sole-authorship I accept responsibility for this 
narrative as my current composition of becoming and being Irish-Pākehā. The following excerpts are necessarily brief, inevitably subjective, and partial.

\section{A Narrative of Belonging}

\subsection{Belonging to a Place of Origin}

Growing up, being Irish (and Catholic) meant fierce loyalty to family, faith, land, language, country, and especially past, present, and future generations. This loyalty was tangibly expressed across the generations, through familial relationships, political activism, and community service.

My ancestors lie peacefully in southwest Ireland, where generational narratives and complex histories are woven into a way of knowing, being, and doing, where the land holds stories and visible reminders of earlier troubles, where physical and eternal worlds meet in 'thin places', where the weather is not nearly as rainy as people think (or it is), where things can suddenly turn desperate and bleak-I remember, once, three funerals in a week, where deeply comforting cultural practices offer relief, where the mountains are lower and the skies seem wider than in any other place I have been, and where time is ancient and alive, there's enough of it, and grabbing ' $a$ coffee to go' seems ridiculous. But today the clocks have stopped - a family member in Ireland died this afternoon and more than anything else in the world I wish I could be there for the wake.

Here I begin with my great-great-grandparents, Mary and John Keohane, who raised nine children on a farm at Ardra, near Bantry Bay in County Cork. During the Great Hunger, Mary took baskets of food to starving families in nearby valleys, and John helped bury the dead. As well as being kind and hardworking, they were also forward looking. The farm could not support them all, so action was needed. In the 1860s, like so many other Irish parents, Mary and John began sending their children away. A son and a daughter went to North America, and eventually five daughters to New Zealand. As was common in those days, the eldest son remained at home, to farm the land, and the eldest daughter also stayed, to help her mother. Our story does not follow historical narratives of fleeing victims of the famine escaping from colonial oppression. It speaks of agency and, yes, adventure and a refusal to allow freedom to be constrained by injustice and difficult circumstances. But all that came at a terrible cost, as I indicated earlier.

In the next generation, my Irish cousins-young women and men-fought in the Irish War of Independence and the Irish Civil War. They were imprisoned in Dublin's infamous Kilmainham Gaol-that miserable place where Irish political prisoners were executed during the 1916 Easter Rising that sought to end British rule. In letters to their mother (Margaret, my great grandmother's sister), my cousins accepted imprisonment as part of the struggle and the price paid for their political convictions. It was Margaret's granddaughter Toxi, the one with a beautiful smile, huge heart, sharp intelligence, and gorgeous humour, who welcomed me home to Ireland when I returned 30 years ago. It wasn't my first visit to Ireland, but it was the welcome I will always remember.

My great-grandmother Catherine was born in Ardra in 1863, shortly before the start of the Waikato Land Wars and the unjust land confiscations from Māori tribes at Ihumātao. ${ }^{9}$ Catherine arrived in Aotearoa as a 21-year-old with her sister and was welcomed by Uncle O'Mahoney (Mary's brother). They settled in a small town, around 70 miles from Auckland, with two older sisters who had arrived earlier. Another sister came later. They say Catherine wept every night for a year, then pulled herself together and began to make a life here. She raised nine children, lost a son swept away in a river, buried two husbands, ran a business, laid out the dead, went to church every Sunday and, like her mother, was endlessly kind and generous towards families needing support. Catherine was terribly hardworking, but somehow made time to brew beer. Everyone says she had a great sense of humour. She was an Irish speaker, but lived in a land where Irish wasn't spoken, so it stayed with her.

9 See Mason Durie (1998, chp. 5) for detailed evidence of and State mechanisms to enable Māori land alienation and dispossession including through, but not limited to, confiscations across the country, as well as discussion of Māori strategies for land revitalisation. Additionally, Vincent $\mathrm{O}^{\prime}$ Malley (2016) for an overview of the events that produced the confiscations and the Waikato Land Wars. (Hancock et al., forthcoming) also provides background on these events. 
My New Zealand-born grandmother (Elizabeth) was tall, slim, and dignified. Lizzie, as she was known, collected china with money she made from her extraordinary talent as a seamstress. Like her mother, people entrusted her with their troubles. She was known for her kindness, her listening heart, and for laying out the dead. She was also formidable and certain about her convictions. Her brother, Alf, returned to Ireland to work on the farm, when their cousins were imprisoned and eventually managed to secure their release. Her sister became a Catholic nun, known as Sister Cyril, who dedicated her life to a small, remote Māori community in Northland, where she was greatly loved and is buried.

My mother was also tall, slim, and dignified. I can still see her, leaning across a shop counter listening intently to a story more important than anything else she had ever heard, which is how she listened to all the stories told to her, knowing it was told by someone society ignored. She was always booking up groceries for families who had no money (many of whom were Māori) and occasionally a van-load of goods for a tangi (a Māori funeral), bills that everyone knew could never be paid. She often went to the linen cupboard looking for something to give away and brought strangers home to stay.

My great/grandmothers, I imagine, had minimal contact with Māori individuals/families/communities and knew little of the destruction wrought in Aotearoa by colonisation. While peacefully living their lives on (former) Māori territories, Māori communities were struggling for physical and cultural survival and actively resisting further invasion of their homelands. Assumptions of European superiority prevailed in towns and cities, in developing institutions, in local and national discourses, wherever settlers were. ${ }^{10}$ In other words, European settlers centred themselves and sought to assimilate Māori. Additionally, prior to World War II, most Māori lived in rural areas, mainly within their own tribal districts. Rapid urban migration by Māori did not occur until after the Second World War and, by the mid-1980s, nearly 80\% of Māori lived in towns or cities. My mother's connections to Māori were more pronounced, not only because of broader social changes, but also because she/we lived in communities where many Māori families lived. She had interpersonal encounters and connections with Māori that defied the "simple binaries" that characterised settler-Indigenous relations as "bad-colonizer and good-Māori". ${ }^{11}$ But the education system failed to teach any version of New Zealand history, so my mother and other Pākehā of her time (and mine) did not learn about past and contemporary injustices perpetrated against Māori. Concerted Māori efforts to exercise sovereignty and retain their lands and other resources, including their culture, were also actively undermined and rendered invisible, but remain unceasing. ${ }^{12}$

My mother suffered in other ways, but refused to allow the travail of her life to overcome her dignity or define her. That was because she was her mother's daughter, and her mother was her mother's daughter, and her mother, my Irish great-grandmother, was her mother's daughter, who was also my great-great Irish grandmother. I was raised to think that I was one of 'these women' - upright, steadfast, kind, generous, hardworking, and resilient, with an identity unequivocally Irish and made in New Zealand.

My Irish cousin Alec (Toxi's brother) came to Aotearoa-New Zealand unexpectedly at the very moment I was to hand in my PhD in my 57th year! How wonderful, I thought, 'the Irish sent him to me'. He was seventy then and intensely interested in everything concerning New Zealand's Indigenous peoples, including my work on the campaign, \#ProtectIhumātao. His attention quickly focussed on the ancestors of the young Māori women leading this campaign and the future generations (theirs and mine) affected by everything we are fighting for- the whenua (land), recognition of Indigenous status, justice, and self-determination, the importance of cultural heritage landscapes and more. "You must keep going for them," he said, meaning their tüpuna (ancestors), the young women, and the land. "You must never give up." Something about his words, or was it his fervour, reminded me of the cross at Kilmainham Gaol that marks the spot where the Irish freedom fighters were executed.

10 See Bell (2008) for a succinct explanation of the complex mix of historical, geo-political, and demographic factors influencing evolving contact between Māori and Pākehā. Additionally, see McCreanor (2005) for a cogent discussion on (disturbing) Pākehā discourses that inform Pākehā identities and support various forms of domination that discount and marginalise Māori.

11 See (Alison Jones 2020, p. 215).

12 See Mason Durie (1998) for a cogent explanation of ongoing Māori self-determination and autonomy in the face of a concerted assimilationist agenda of the State. Also, Mason Durie (2005) outlines contemporary examples of endurance and resilience. 
That cross challenges me oceans away to turn towards Indigenous struggles for justice and remember that those struggles are connected to my own freedom.

\subsection{Belonging to a Place of Birth}

I was born in a former army hospital beside Maungakiekie, a volcanic peak in Ngāti Whātua tribal territory, in the heart of Tāmaki Makaurau-Auckland. Despite centuries of occupation, actions of the settler government left Ngāti Whätua effectively landless and for so long the Crown failed to acknowledge their repeated calls for justice over breaches of Te Tiriti o Waitangi. ${ }^{13}$ Growing up, I didn't know whose territory it was, what had gone on before in this place, or even the Māori name of 'my' city. I knew Maungakiekie as One Tree Hill and was educated alongside Māori kids who probably had whakapapa connections (ancestral affiliations) to Ngāti Whātua, but the significance of their identity was never recognised in school.

The beauty of my surroundings worked on my imagination and heart from a young age. I especially loved the Manukau Harbour, never far from sight. As a teenager, listening to the aunts tell stories of the sisters coming from Ireland, I imagined taking a return journey for them, leaving from this harbour.

I am the second youngest of seven children. Much of my childhood was spent living in cramped accommodation attached to a succession of small dairies (in New Zealand, a convenience store) that my parents managed or owned. Some of 'the shops', as we called them, were situated in low-income, low-lying areas, where many Māori families lived; a few in wealthy suburbs where mainly Pākehā families enjoyed harbour views; and others in places in between. I was 50 when I realised that, growing up, I had lived in 16 houses in nine communities. I got off lightly; my older sisters lived in 32 houses in 16 communities, but that is another story. We were self-styled outsiders (arriving some place, staying a while, then moving on) and partial insiders (due to our residence, however temporary). Our itinerant unpredictable life disrupted connections that create a sense of belonging to place. However, crossing borders, the observations of my parents and the people around us alerted me to privilege and difference. Our life was an incredible education for a writer and something of an adventure.

A Māori woman called Mary (not her real name) had a lasting impact on me. Her extraordinary relational presence, huge intelligence, and ethical sensibility arrived rather loudly one day and never left. Mary worked alongside my parents for years and became my mother's other daughter and lifelong friend. She was always kind, often laughing, and forever telling stories about cultural-spiritual realms I knew nothing of, but which felt strangely familiar. Later she went to university, learnt te reo Māori (the Māori language) and reclaimed her birth name Mere (not her real name). Mere sat next to me at my mother's funeral, and I spoke for our family at hers. Only aroha (an all-encompassing love) can explain Mere's relationship with my family; she witnessed and weathered our storms but never judged us.

As an undergraduate student in the early 1980s, I witnessed Māori-led political movements and joined anti-racism efforts and protests supporting Te Tiriti o Waitangi. I began to question power relations and to realise that I and my kind (New Zealanders of European descent) had benefited from histories, politics, and structural arrangements that privilege all things Pākehā at the expense of Māori peoples/communities, interests, and ways of being. My people enjoyed unearned advantages and a conferred dominance that came with being Pākehā in a Pākehä-dominated society, which critical scholars refer to as 'white privilege'. ${ }^{14}$ This meant racism was never part of my experience; being Pākehā shielded me from its insidious forms and damaging effects. Seeing myself as 'a Pākeh"̄' was an imaginative leap that meant embracing a new and unfathomable identity that came with

13 Te Tiriti o Waitangi was an agreement signed in 1840 between representatives of the British Crown and most (over 500) Rangatira (Māori leaders). This treaty is part of the constitutional framework of New Zealand. Different language versions-Māori (Te Tiriti) and English (The Treaty)—in effect produced two treaties with different meanings. Most rangatira signed the Māori text. In 1975, the New Zealand Government established a permanent commission of inquiry—the Waitangi Tribunal—to hear Māori claims of Tiriti breaches and has since begun to recognise and remedy its failure to honour Tiriti promises, including the Ngāti Whātua land claim (Waitangi Tribunal 1987).

14 Borell et al. (2018) further explains: “The invisibility of conferred privilege supports and perpetuates disparities by allowing those who have advantage to assign their fortune to merit and others' disadvantage to personal blame, bad luck, or lack of hard work rather than acknowledging and understanding structural forces" (p. 35). See also, for example, Peggy McIntosh (1989), Steve Matthewman (2017), and Bell (2020). 
ethical-political commitments. Other European New Zealanders could just as easily and unconsciously ignore such considerations and commitments, and on a given day I could/still can, too- that's how white privilege works, it is deeply ingrained.

Back in the day (and now), the sorts of issues Māori were addressing_land, language, family/community wellbeing, self-determination -interested me. I was drawn to work with and for Māori peoples/groups and diverse underserved communities. My efforts focused on community-led initiatives, capability and capacity-building, community-storytelling, and Tiriti-based policy and practice. After thirty some years, I was ready for a sabbatical, but it was not to be.

One day in March or April 2015 Brendan, a Pākehä friend with similar interests, knocked on my door. Over a cuppa, he told me about what was happening at Ihumätao, near where I live. I was very reluctant to get involved. I imagined (rightly) the campaign would go on for years, consume whole lives, and face interminable challenges. I listened quietly for a way out, but couldn't find one. I could not ignore Brendan's concerns or the politics in play at Ihumätao as he explained them. Soon afterwards I took my place next to him at hui (gatherings) discussing strategy with the campaign co-founders and their Pākehā supporters.

Over the next five years, Brendan and I rarely missed a weekly meeting. He became a campaign researcher and activist, while I became a campaign writer and advisor. Sometime during the first year, I asked him if we could be related. "My great-grandmother's sister married a Corbett (Brendan's last name) from Hikutaia." "Well, cuz," he replied, "that's my father's family!" We laughed and exchanged stories of Irish connections. Regardless of blood, we had become kin joined by common commitments.

By then I was also feeling growing affection for the Indigenous Peoples of Ihumātao I'd come to know. I had joined their campaign, seeking to work in solidarity with them, to reclaim their whenua (land) and protect it from destruction. Unlike Brendan, I had no prior relationships with Ihumätao or its Indigenous peoples. Through subsequent years of engagement, they gradually began to introduce me to this often windswept but always beautiful cultural heritage landscape, and its contested history. I developed relationships with the campaign co-founders, most of whom are half my age, and joined them in political actions.

I recall the haerenga (journey) by bus to the capital city Wellington, to present a petition to Parliament. A bus company owner with blood ties to Ihumatao offered his services. Along the way, we visited prominent sites of Māori land occupations. We enjoyed the manaakitanga (unconditional caring for others) offered by hau kāinga (the home people) and listened to their heart-breaking/heart-warming stories. We, Māori and Pākehā, slept on mattresses on the floor of wharenui (Māori meeting houses) and the kuia (Māori female elders) next to me whispered riveting and hilarious stories. On the bus, we changed seats to get to know one another better.

One morning I sat next to Pania Newton, a campaign co-founder and spokesperson, with whom I now work closely. She was in her mid-twenties when she presented the campaign's first submission to a Parliamentary Select Committee. "I don't know if I can do this," she said quietly, just before we entered the rather daunting committee meeting. I couldn't begin to imagine the responsibility she was shouldering or what she was thinking or feeling. I gently replied, "Pania, I will stand beside you and behind you, for as long as you stand beside me and in front of me." As the words left my lips, I realised I had made a promise I could never break. After a pause, she said, in that lovely lyrical tone she uses when faced with the inevitable, "Oh, alright then", and off we went. That day, it seemed to me, her kōrero (talk) in te reo Māori grounded our whole presentation in the humility and mana (authority) of the peoples of Ihumātao. I felt in awe of her courage and leadership. On other days she reassured me when I felt uncertain, her encouragement enabling me to go on.

Back on the bus, I connected my laptop to Pania's so I could access her wi-fi. Working together, we sent bulk emails, with an attached letter outlining core campaign issues, to every Member of Parliament. The country road was full of potholes and, despite excellent driving, we bounced around in our seats, making the job almost impossible. We laughed, as utter frustration was the only alternative. Perhaps, as different as we are from one another, Pania and I share human qualities of tenacity and perseverance. The next day we marched through the streets of Wellington to Parliament joined by hundreds of supporters.

Full of aroha and learning, that journey was an extraordinary privilege that deepened my relationships to the whenua and peoples of Ihumātao. This whenua now has the nation's highest heritage status listing but, 
six years on, the struggle for justice continues, and I need all of who I am-heart, mind, body, spirit-and my ancestral inheritances to negotiate the complexities and challenges I meet every day in Māori-Pākehā relations.

\section{Inspiriting Indigenous-Settler Relations}

In the above narrative of belonging, I attempted to begin to express a storied account of a complex, diasporic Irish-Pākehā identity, which others may describe differently. I was challenged to weave together and make meaning of selected relationships, intergenerational stories, and lived experiences. Lives are not easily contained in short stories (Brinkmann and Kvale 2015) and personal narratives are inevitably "incomplete, tentative, and revisable" (Ellis 1997, p. 129); my narrative is no exception. Yet, my story-in-progress has created resources for identity-making through kinship that seem to inspirit (from my point of view, at least) the Māori-Pākehā engagements I am part of.

I rely on cues to tell me that a relationship is working or not, and such cues also operate in my relationships with Māori. Do I feel a heart connection? Is there kindness, respect, and laughter? Is there authentic integrity? Can I be honest with this person and can they be honest with me? That connection, that kindness, respect, and laughter, that integrity, that honesty may have many expressions. Perhaps a sudden beaming smile when someone sees you unexpectedly, or the lift in a person's tone of voice when they realise it is you on the phone, or a shared look when an outrageous assumption is expressed in a meeting, or perhaps an invitation to join a Facebook group that mainly exists for whānau, or a late-night text message seeking urgent assistance knowing you/your colleague will respond, or a scolding when cultural protocols are inadvertently breached because, for the relationship to work, there must be honesty and truth-telling. Seeking to embody the qualities and commitments of my maternal ancestors, grounds, enlivens, and emboldens possibilities for authentic kinship with Māori-and that is what 'to inspirit' means.

\subsection{On Relatedness}

This research expresses an urgent human longing for kinship; for acknowledgement of and right relationships with the places and peoples to whom we belong. My exploration of a certain kind of identity and how that identity relates to Indigenous peoples sits within a broader project (Hancock 2018) focussed on disrupting colonial relations of domination in favour of "relations of co-existence" (Bell 2014, p. 192). Those relations seek to understand and enact "a complex reciprocity" (Jones and Jenkins 2008b, p. 187) that is grounded in becoming and being who you are and accepts the impossibility of knowing all about different others (Hoskins 2010; Hoskins and Jones 2012). My conception of becoming and being Irish-Pākehā offered here suggests that "a call to relationship" is also "a call to action" (Waitere 2008, p. 45). It recognises that "context and history, relationships and commitments do matter and can inform and shape the taking of political decisions" (Hoskins and Jones 2012, p. 5). In that sense, it is as much an identity-making project as a future imaginary for Pākehā responsibility in Indigenous-settler relationships. Both require "working the hyphen" (Jones and Jenkins 2008a, p. 187) which, in my case, exists between two places of belonging and in my (Pākehā) relationships with Māori.

A diasporic Irish-Pākehā identity informs my political positioning in Aotearoa in significant ways. Being Irish distinguishes and enriches who I am as a Pākehā. A "fluid, reflexive and inclusive" diasporic identity shields me from the troubling confusion and unimaginable loss represented in a dismembered Pākehā identity; a settler identity dislocated from ancestral origins and relations (Nash 2008, p. 273). I accept, too, that other Pākehā may not be troubled at all or very much by such confusion or loss. Appreciating Irishness as a source of identity and diversity among Pākehā also alerts me/us to be open to and learn from Māori difference/s. Māori philosopher Te Kawehau Hoskins argues that who we are (as people) matters more than what we are (Pākehā, middle-class, and so on) (Hoskins and Jones 2012, p. 5). However, she also highlights an ethical obligation to attend to and preserve difference (Hoskins 2010). Staying alert when engaging with others (while also negotiating the risks, challenges, and uncertainties of relationships), can create possibilities for ethical learning and 
action. Just as identifying as Irish-Pākehā contributes to the collective identities of Pākehā/European New Zealanders for example, so too tribal differences enrich Indigenous identities.

\subsection{Doing Kinship within and outside Family}

Doing kinship with selected kith and kin, the dead and the living, creates relational possibilities for Irish-Pākehā. Those of us who claim Irish descent can create new bonds and better appreciate the relational complexities attached to our roots and sense of rootedness (Nash 2008). When I met my Irish cousins 30 years ago, it was as if we already knew each other. The place of my ancestors felt familiar and comforting. Our coming together reunited the family, bridged places/histories in our genealogical narratives, and continued a relationship across oceans that wants to thrive because it matters. What all this means for the next generation/s, only they can say, but the possibility remains for them to make and remake deeply enriching relationships as my cousins and I have done in our generation.

Likewise, supporting the struggle for justice at Ihumātao has brought me into a closer relationship with that whenua, its stories, and Māori who have known that place longest and best. At a face-to-face level, I notice my relationships with the people I know at Ihumātao are very human; full of laughter and learning, sometimes uneasy or confounding, dedicated and loving. As with other close relationships with Māori, they are at the same time "at risk from the weight of the past, [and] in that sense very special, fragile and always compelling" (Hancock 2018, p. 244). Each time we meet, I begin, again and again, to engage in a generative struggle of and for significant relationships that extend across the generations - theirs and mine-and between us. I am reminded that kinship outside blood relations is continually made and can be sustained (Lipman and Nash 2019). What matters is showing up, engaging in authentic relationships, sticking with the kaupapa (principles, purpose, programme), and doing whatever it takes for which there can be no detailed explanation (Jones 2012; Hancock 2018). I am grateful to be able to stand on the whenua knowing I have been welcomed by its Indigenous peoples. My relationship with the whenua is changing how I feel about where I live, who and what I am, and my sense of what truly matters.

\subsection{Affinities and Ambivalences}

An Irish-Pākehā identity is always already in relation to Indigenous Māori. Like Glynn (2013) and some of those in Kearney (2016) study, my Irish heart feels a sense of affinity (to use Nash's term) with particular Māori ways of knowing, being, doing: The significance of hospitality and of manaakitanga (welcoming, caring for others); a feeling for the land and for the whenua; an appreciation of thin places and for wāhi tapu (a scared place). As well, there is a shared acceptance of interminable struggles for justice or, as Māori say, ka whawhai tonu matou ake ake ake (the struggle without end). Such affinities must never be confused as one and the same, but perhaps offer a human connection that can support solidarity for justice. Ongoing Māori experiences of colonisation are historically located, context-specific, and uniquely felt, similar in some respects to the colonial project in Ireland and other places, but with differences that require close attention and critical understanding.

How I as an Irish-Pākehā engage with Māori is also bound up with being a member of the dominant settler group. When my Irish cousin explained, "The worst thing you can call a person in the west of Ireland is a settler, because the settlers [the British] were the invaders," my reaction was visceral—anger towards the colonial invaders and discomfort because, in Aotearoa, my people are undeniably settlers. I cannot escape this uncomfortable contradiction, (which Nash refers to as antipathies and ambivalences) or relate ethically towards Māori unless I accept its tensions, ambiguities, and uncertainties. Making peace with all this complexity requires openness, a willingness to learn, a certain clarity about what you can and cannot/should not do, a lot of emotional and moral stamina, and wisdom. I look to significant ancestors and others who have embodied an ethical stance, an orientation, or way of being that can inform my relationships with Māori. I try to behave like them. 


\section{Concluding Thoughts}

\subsection{On Methodology}

If making an Irish-Pākehā identity is about making relations with ourselves, with our past, present and future generations, with significant places of belonging, and with Indigenous Māori, then it is unending and unsettled work. Woven into a particular life story are relations with/stories of multiple others, places and nations, and in my case Indigenous peoples. The concrete details of lived experiences can help to make such relations, and the abstract ideas we use to think about them, more visible (Bell 2020).

The narrative inquiries, excerpts and observations in this paper belong to a larger project. Always, so much more could and should be said. Why these inquiries and not others? Why those stories/observations and not these ones? It is unwise to assume that any set of guiding questions is complete or fixed in stone-such an approach quickly becomes intellectually limited, emotionally constrained, and worse, formulaic. At best, guiding questions create an opening that may help to inspire ethical-political narrative work, even so they can always benefit from review, refinement, or reconstruction. Did I answer all my own questions? Possibly not, but they remain here for future consideration.

Observations or interpretations become fixed on a page, as if they too are complete and set in stone. However, an open-minded, reflexive approach challenges critical scholars to embrace the ethical-political work of constant engagement and renegotiation. When exploring one path of inquiry, I can so easily/inadvertently overlook others (well-worn or not yet taken) or seemingly erase analyses of the broader historical context that must be interwoven for a closer/critical inspection/appreciation of the ethical-political dimensions of decolonising work.

My approach here favoured an exploration of relational qualities and broad political commitments I can lean on when engaging with Māori. Nash's scholarship offers me helpful-hopeful ideas for understanding an Irish-Pākehā identity through the lens of doing kinship. Applying other lenses will generate other insights. However, the Māori-Pākehā relations I daily inhabit remind me that it is not possible in a single essay to adequately address all the implications that arise in a discussion on becoming and being Irish Pākehā. Catherine Nash (2008) mammoth project on being of Irish descent and the politics of belonging-some 350 pages—confirms that humble fact. Accept limitations and imperfections, I say to myself. Critical observations or ethical-political nuances that may operate in face-to-face relations (because they have somehow over a lifetime become embodied) can strangely become lost or found when recounting personal narratives in text. Stories that are any good and told well enough have something to teach; even lacuna, omissions or naiveties create openings for future work or may productively focus a reader's attention.

\subsection{On Becoming and Being Irish-Pākehā}

Becoming and being Irish-Pākehā offers geographically distinct resources, kin relationships, political challenges, and imaginative space for making an identity. I cannot recall a time "when I was not aware of Ireland as a place and the place where my people came from" (Kearney and Andrew 2019, p. 363), but Aotearoa as a place and my rich relationships with Māori have also worked their way into my heart and my imagination, and without them I cannot exist. Both places of belonging offer multiple homes/lands where I am learning how to stand upright, while positioned differently in each, and to know myself better. Knowing to whom and where I belong is not only ever-evolving, but also always/already in relation to Māori to my ancestors and to both my countries; they have all written their names on my heart and call me to work for justice.

Funding: This research received no external funding.

Acknowledgments: The author would like to thank family members, Pania Newton, external reviewers and other colleagues: Alison Jones, Tim McCreanor, Lincoln Dam, and Shirley Hager for their insightful comments. The author is grateful to Māori colleagues at Ihumātao for developing her understanding of injustices there. 
The author is especially grateful to Rose Yukich for her editorial review of earlier drafts and collaborative conversations. The author acknowledges the Social Futures Research Hub (Faculty of Arts, University of Auckland) for providing space and encouragement to work on this paper, and the ongoing support of Te Puna Wānanga, The School of Māori and Indigenous Education (Faculty of Education and Social Work, University of Auckland).

Conflicts of Interest: The author declares no conflict of interest.

\section{References}

Archibald, Jo-ann. 2008. Indigenous Storywork: Educating the Heart, Mind, Body and Spirit. Vancouver: University of British Columbia Press.

Archibald, Jo-ann, Jenny Lee-Morgan, and Jason De Santolo, eds. 2019. Decolonising Research: Indigenous Storywork as Methodology. London: Zed Books.

Bell, Avril. 2006. Bifurcation or entanglement? Settler identity and biculturalism in Aotearoa New Zealand. Continuum: Journal of Media E Culture Studies 20: 253-68.

Bell, Avril. 2008. De/centering and the legacy of settler colonialism. Cultural Studies 22: 850-69. [CrossRef]

Bell, Avril. 2014. Relating Indigenous and Settler Identities: Beyond Domination. London: Palgrave Macmillian.

Bell, Avril. 2020. Reverberating Historical Privilege of a "Middling" Sort of Settler Family. Genealogy 4: 46. [CrossRef]

Bell, Avril, and Anne McGuire. 2019. Awkward Conversations about Pākehā Identity. [Interview]. Afternoons with Jesse Mulligan Archive; Radio New Zealand. November 17. Available online: https://www.rnz.co.nz/ audio/player?audio_id=2018722187 (accessed on 23 November 2020).

Bidois, Vaughan. 2013. A genealogy of cultural politics, identity and resistance: Reframing the Māori-Pākehā binary. AlterNative: An International Journal of Indigenous Peoples 9: 142-54. [CrossRef]

Bishop, Russell. 1996. Collaborative Research Stories: Whakawhanaungatanga. Palmerston North: Dunmore Press.

Borell, Belinda, Helen Moewaka Barnes, and Tim McCreanor. 2018. Conceptualising historical privilege: The flip side of historical trauma, a brief examination. AlterNative 14: 25-34. [CrossRef]

Brinkmann, Svend, and Steinar Kvale. 2015. InterView: Learning the Craft of Qualitative Research Interviewing, 3rd ed. Thousand Oaks: Sage.

Bruner, Jerome. 1986. Actual Minds, Possible Worlds. Cambridge: Harvard University Press.

Clandinin, D. Jean, and F. Michael Connelly. 2000. Narrative Inquiry: Experince and Story in Qualitative Research. San Francisco: Jossey-Bass Publishers.

Coles, Robert. 1989. The Call of Stories: Teaching and the Moral Imagination. Boston: Houghton Mifflin.

Consedine, Robert, and Joanna Consedine. 2012. Healing Our History: The Challenge of the Treaty of Waitangi, 3rd ed. Auckland: Penguin Books.

Durie, Mason. 1998. Te Mana, Te Kāwanatanga: The Politics of Māori Self-Determination. Auckland: Oxford University Press.

Durie, Mason. 2005. Ngā Tai: Tides of Māori Endurance. Auckland: Oxford University Press.

Ellis, Carolyn. 1997. Evocative autoethnography: Writing emotionally about our lives. In Representation and the Text: Reframing the Narrative Voice. Edited by William G. Tierney and Yvonne. S. Lincoln. Albany: State University of New York Press, pp. 115-39.

Fitzpatrick, Esther. 2018. A story of becoming: Entanglement, settler ghosts and postcolonial counterstories. Critical Studies Critical Methodologies 18: 43-51. [CrossRef]

Fleras, Augie, and Paul Spoonley. 1999. Recalling Aotearoa: Indigenous Politics and Ethnic Relations in New Zealand. Auckland: Oxford University Press.

Frank, Arthur. 2004. The Renewal of Generosity: Illness, Medicine and How to Live. Chicago: The University of Chicago Press.

Frank, Arthur. 2010. Letting Stories Breathe: A Socio-Narratology. Chicago: The University of Chicago Press.

Glynn, Ted. 2013. Me nohotai, mahitahi, haeretahi tātou: Collaborative partnerships between indigenous and non-indigenous researchers (Māori and Pākehā). In Culturally Responsive Methodologies. Edited by Mere Berryman, Suzanne SooHoo and Ann Nevin. Bingley: Emerald Publishing Group Limited, pp. $35-52$.

Hancock, Frances. 2018. Becoming Just, Doing Justice: The Ethics and Politics of Māori-Pākehā. Doctoral thesis, University of Auckland, Auckland, New Zealand. Available online: http://hdl.handle.net/2292/37063 (accessed on 23 November 2020). 
Hancock, Frances. 2019. 'Who said this?' Negotiating the ethics and politicis of co-authorship in collaborative community text-making. In Narrative and Metaphor: Innovative Methodoliogies and Practice. Edited by Sandy Farquhar and Esther Fitzpatrick. Dordrecht: Springer, pp. 97-117.

Hancock, Frances, and David Epston. 2008. The craft and art of narrative inquiry. In The Sage Handbook of New Approaches to Management and Organization. Edited by David Barry and Hans Hansen. Thousand Oaks: Sage, pp. 485-502.

Hancock, Frances, Jenny Bol Jun Lee-Morgan, Pania Newton, and Tim McCreanor. Forthcoming. The case of Ihumātao: Interrogating competing Indigenous and corporate visions of the future. Unpublished manuscript (consulted 22 November 2020). New Zealand Sociology, 35.

Hancock, Frances. Forthcoming. An afterward: Being in the relationship. In The Gatherings: Reimagining Indigenous-Settler Relations. Co-Authored by Shirley N. Hager and Mawopiyane. Toronto: University of Toronto Press.

Hoskins, Te Kawehau. 2010. Māori and Levinas: Kanohi ki te Kanohi for an Ethical Politics. Doctoral thesis, University of Auckland, Auckland, New Zealand. Available online: http://hdl.handle.net/2292/6089 (accessed on 23 November 2020).

Hoskins, Te Kawehau, and Alison Jones, eds. 2012. Introduction. He aha te Kaupapa? Critical conversations in Kaupapa Māori [Special issue]. New Zealand Journal of Educational Studies 47: 3-9.

Jones, Alison. 2012. Dangerous liaisons: Pākehā, kaupapa Māori and educational research. New Zealand Journal of Educational Studies 47: 100-12.

Jones, Alison. 2020. This Pākehā Life: An Unsettled Memoir. Wellington: Bridget William Books.

Jones, Alison, and Kuni Jenkins. 2008a. Rethinking collaboration: Working the Indigene-colonizer hyphen. In Handbook of Critical and Indigenous Methodologies. Edited by Norman Kent Denzin, Yvonne Sessions Lincoln and Linda Tuhiwai Smith. Thousand Oaks: Sage, pp. 471-86.

Jones, Alison, and Kuni Jenkins. 2008b. Invitation and Refusal: A Reading of the Beginning of Schooling in Aotearoa New Zealand. History of Education 37: 187-206. [CrossRef]

Kearney, Celine. 2016. Southern Celts: An Investigation of How People with a Celtic/Gaelic Background Live out Their Traditions in Aotearoa-New Zealand. Doctoral thesis, Victoria University, Melbourne, Australia. Available online: uir.vu.edu.au/32765/3/KEARNEY\%20Celine-thesis_nosignature.pdf (accessed on 23 November 2020).

Kearney, Celine, and Martin Andrew. 2019. Southern Celts: Voices from Aotearoa New Zealand. Studi Irlandesi. A Journal of Irish Studies 9: 347-67. [CrossRef]

King, M. 1999. Being Pākehā Now: Reflections and Recollections of a White Native. Auckland: Penguin Books.

Lipman, Caron, and Catherine Nash. 2019. Domestic genealogies: How people relate to those who once lived in their homes. Cultural Geographies 26: 273-88. [CrossRef]

Liu, James Hou-fu. 2005. History and identity: A system of checks and balances for Aotearoa/New Zealand. In New Zealand Identities: Departures and Destinations. Edited by James Hou-fu Liu, Tim McCreanor, Tracey McIntosh and Teresia Teaiwa. Wellington: Victoria University Press, pp. 69-87.

Malva, Shane. 2018. A Struggle with SOUL: Politics of Land, Housing and Metaphysics in Ihumātao. Master's thesis, The University of Auckland, Auckland, New Zealand. Available online: http://hdl.handle.net/2292/43648 (accessed on 23 November 2020).

Matthewman, Steve. 2017. Pākehā ethnicity: The politics of white privilege. In A Land of Milk and Honey?: Making Sense of Aotearoa New Zealand. Edited by Avril Bell, Vivienne Elizabeth, Tracey McIntosh and Matt Wynyard. Auckland: Auckland University Press, pp. 83-94.

Matthewman, Steve, and Douglas Hoey. 2007. Settling in: The Politics of Pākehā Ethnicity. Paper presented at Public Sociologies: Lessons and Trans-Tasman Comparisons, The Australian Sociology Association Conference and Sociological Association of Aotearoa (New Zealand) Joint Conference, Auckland, New Zealand, December 4-7.

Mattingly, Cheryl. 2010. The Paradox of Hope: Journeys through a Clinical Borderland. Berkeley: University of California Press.

McAllan, Fiona. 2013. Speaking-Writing with: Aboriginal and Settler Interrelations. Newcastle upon Tyne: Cambridge Scholars. 
McCreanor, Tim. 2005. 'Sticks and stones may break my bones ... ': Talking Pākehā Identities. In New Zealand Identities: Departures and Destinations. Edited by James Hou-fu Liu, Tim McCreanor, Tracey McIntosh and Teresia Teaiwa. Wellington: Victoria University Press, pp. 52-68.

McCreanor, Tim, Frances Hancock, and Nicola Short. 2018. The mounting crisis at Ihumātao: A high cost special housing area or a cultural heritage landscape for future generations. Counterfutures: Left thought and Practice Aotearoa-New Zealand 6: 139-48. [CrossRef]

McIntosh, Peggy. 1989. White Privilege: Unpacking the Invisible Knapsack. Available online: https:// nationalseedproject.org/white-privilege-unpacking-the-invisible-knapsack (accessed on 23 November 2020).

Mikaere, Ani. 2011. Colonising Myths-Māori Realities/He Rukuruku Whakaaro. Wellington: Huia Publishers and Te Tākupu, Te Wānanga o Raukawa.

Nash, Catherine. 2005. Geographies of relatedness. Transactions of the Institute of British Geographers 30: 449-62. [CrossRef]

Nash, Catherine. 2008. Of Irish Descent: Origin Stories, Genealogy, and the Politics of Belonging. Syracuse: Syracuse University Press.

Nash, Catherine. 2017. Genealogical relatedness: Geographies of shared descent and difference. Genealogy 1: 7. [CrossRef]

Nelson, Hilde Lindemann. 2001. Damaged Identities, Narrative Repair. Ithaca: Cornell University Press.

O'Malley, Vincent. 2016. The Great War for New Zealand. Wellington: Bridget Williams Books.

Patel, Leigh. 2016. Decolonising Educational Research: From Ownership to Answerability. New York: Routledge.

Royal, Te Ahukaramū Charles. 2012. Politics and knowledge: Kaupapa Māori and matauranga Māori. New Zealand Journal of Educational Studies 47: 30-37.

Smith, Linda Tuhiwai. 2012. Decolonizing Methodologies: Research and Indigenous Peoples, 2nd ed. London: Zed Books.

Waitangi Tribunal. 1987. Report of the Waitangi Tribunal on the Orakei Claim. [Report No. Wai. 9). Available online: https:/forms.justice.govt.nz/search/Documents/WT/wt_DOC_68494556/ReportonOrakeiW.pdf (accessed on 23 November 2020).

Waitere, Hine. 2008. Cultural Leadership: Creating Futures Our Ancestors Can Walk In with Our Children. Journal of Educational Leadership, Policy and Practice 23: 34-47.

Wevers, Lydia. 2006. Being Pākehā: The politics of location. Journal of New Zealand Studies 4: 1-9. [CrossRef]

Publisher's Note: MDPI stays neutral with regard to jurisdictional claims in published maps and institutional affiliations.

(C) 2020 by the author. Licensee MDPI, Basel, Switzerland. This article is an open access article distributed under the terms and conditions of the Creative Commons Attribution (CC BY) license (http://creativecommons.org/licenses/by/4.0/). 